\title{
Degradation of the Herbicide Paraquat by Photo-Fenton Process: Optimization by Experimental Design and Toxicity Assessment
}

\author{
Alam G. Trovó, ${ }^{*, a}$ Oswaldo Gomes Junior, ${ }^{a}$ Antonio E. H. Machado, ${ }^{a}$ \\ Waldomiro Borges Neto ${ }^{a}$ and Jader O. Silva ${ }^{b}$
}

\author{
anstituto de Química, Universidade Federal de Uberlândia (UFU), CP 593, 38400-902 Uberlândia-MG, Brazil \\ ${ }^{b}$ Departamento Municipal de Água e Esgoto de Uberlândia (DMAE), 38400-606 Uberlândia-MG, Brazil
}

Este trabalho descreve a influência e otimização dos reagentes de Fenton (concentração de $\mathrm{Fe}^{2+}$ e $\mathrm{H}_{2} \mathrm{O}_{2}$ ) na eficiência da mineralização do herbicida paraquat (PQT, $50 \mathrm{mg} \mathrm{L}^{-1}$ ) em água, após 60 min (equivalendo a $642 \mathrm{~kJ} \mathrm{~L}^{-1}$ de radiação UVA acumulada) de tratamento por processo foto-Fenton em escala de laboratório, usando planejamento composto central (CCD). Sob condições otimizadas, experimentos cinéticos foram feitos, avaliando a remoção do PQT, sua mineralização e toxicidade em escala de laboratório, usando irradiação artificial, e em planta piloto sob irradiação solar. A mesma eficiência de remoção e mineralização do PQT foram obtidas em ambos os reatores utilizados. A toxicidade das amostras, estimada em termos de mortalidade de Artemia salina, diminui simultaneamente com o decaimento da concentração de PQT, sugerindo a formação de intermediários de menor toxicidade. Dessa maneira, o processo foto-Fenton/solar pode ser considerado uma alternativa viável para o tratamento de águas residuais contendo PQT.

This study describes the influence and optimization of Fenton's reagent (concentration of $\mathrm{Fe}^{2+}$ and $\mathrm{H}_{2} \mathrm{O}_{2}$ ) on the efficiency of mineralization of the herbicide paraquat (PQT, $50 \mathrm{mg} \mathrm{L}^{-1}$ ) in water, after $60 \mathrm{~min}$ (equivalent to $642 \mathrm{~kJ} \mathrm{~L}^{-1}$ of accumulated UVA radiation) treatment by photo-Fenton process in laboratory scale, using central composite design (CCD). Under optimized conditions, kinetic experiments were done, evaluating the PQT removal, its mineralization and toxicity in laboratory scale, using artificial irradiation, and in a pilot plant under solar irradiation. The same removal efficiency and mineralization of PQT were obtained in both reactors. The toxicity of the samples, estimated in terms of mortality of Artemia salina, decreases simultaneously with the decay of concentration of PQT, suggesting the formation of intermediates of lower toxicity. In this way, the solar photo-Fenton process can be considered as a viable alternative for the treatment of wastewater containing PQT.

Keywords: pesticides, detoxification, pilot plant, wastewater treatment, solar light intensity

\section{Introduction}

Since 2008 Brazil has overtaken the United States in pesticides consumption, becoming the largest consumer. ${ }^{1}$ The herbicide paraquat dichloride (PQT, Figure 1) has been widely used for application in post-emergence of weeds and also as desiccant. ${ }^{2}$ Its residence time in soils can vary from 1.4 to 7.2 years depending on the concentration, soil characteristics (organic matter), temperature and rainfall. ${ }^{3}$ In river water samples, it has been observed that PQT is not easily microbiologically degraded, since, even after 56 days of incubation, more than $80 \%$ of the initial concentration remains unchanged, suggesting to

*e-mail: alamtrovo@iqufu.ufu.br

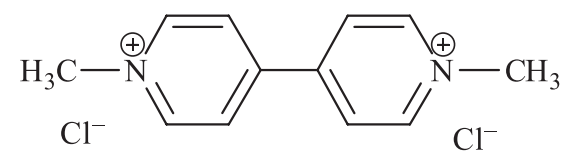

Figure 1. Chemical structure of paraquat dichloride.

PQT considerable recalcitrance. ${ }^{4}$ In addition, PQT is polar, showing high solubility in water, as well as a low octanol-water partition coefficient $\left(\log \mathrm{K}_{\mathrm{ow}}=-4.5\right)$, which provides a great mobility in some soils, arriving easily until the next water supplies. ${ }^{5}$ It has been found in the range of 2-12 $\mathrm{g} \mathrm{L} \mathrm{L}^{-1}$ in groundwater, ${ }^{6}$ and, for example, at average concentration of $0.78 \mu \mathrm{g} \mathrm{L}^{-1}$ in surface waters in Spain. ${ }^{7}$

In acute toxicity studies performed by US Environmental Protection Agency using laboratory animals, PQT has been shown to be highly toxic by inhalation route, having 
been classified in toxicity category I (the highest of four levels). The high toxicity of this compound has also been observed in studies involving the use of bacteria, small crustaceans, algae and aquatic plants. ${ }^{8-12}$ Thus, its presence in the environment can cause adverse effects in aquatic and terrestrial organisms. Therefore, it is desirable for the development and optimization of viable technologies with a focus on disposal of such waste.

Since the traditional biological treatments are not effective in the PQT removing, an alternative can be the use of advanced oxidation processes (AOPs) due to their recognized efficiency in the treatment of recalcitrant organic matter, through the efficient generation of $\mathrm{HO}^{\bullet}$ radicals. ${ }^{13-15}$ From the variety of existing AOPs, particular attention has been given to photo-Fenton process and heterogeneous photocatalysis due to the possibility of use of solar radiation, ${ }^{16}$ reducing the energetic costs. The photo-Fenton process has the advantage to be a homogeneous process, avoiding an additional step of removal of catalyst, usual when dealing with a heterogeneous process. Another advantage is the fact that homogeneous processes favor a greater contact between reagent species, with favorable implications for process performance.

The use of different AOPs for degradation of PQT has been reported, such as immobilized $\mathrm{TiO}_{2}$ and/or in suspension, combined with UV irradiation, ${ }^{17-21}$ UV-ozonation, ${ }^{22,23}$ Fenton's reaction, ${ }^{24}$ activated carbon modified with iron and combined with hydrogen peroxide, and electrochemical methods. ${ }^{25,26}$ However, a study by applying experimental design and response surface methodology that provides conclusions which result in the optimization of Fenton's reagents for PQT degradation was not reported until now. In addition, a kinetic study on the degradation of PQT by photo-Fenton process and toxicity assessment was also not published. Therefore, the aim of the present work was to evaluate the role of each variable $\left(\mathrm{Fe}^{2+}\right.$ and $\mathrm{H}_{2} \mathrm{O}_{2}$ concentration) on the percentage of mineralization of a commercial formulation of PQT (Helmoxone ${ }^{\mathrm{TM}}$ ) at lab-scale, and, under optimized conditions, monitor the kinetic of PQT removal, mineralization, toxicity and the carbon oxidation state (COS) during photo-Fenton treatment not only at lab-scale but also in a solar pilot plant.

\section{Experimental}

\section{Reagents}

All solutions were prepared using ultrapure water. $\mathrm{FeSO}_{4} .7 \mathrm{H}_{2} \mathrm{O}$ (Vetec) was used to prepare aqueous $0.25 \mathrm{~mol} \mathrm{~L}-1 \mathrm{Fe}^{2+}$ stock solution; $\mathrm{H}_{2} \mathrm{O}_{2}(30 \% \mathrm{~m} / \mathrm{m}), \mathrm{H}_{2} \mathrm{SO}_{4}$,
$\mathrm{NaOH}$ and $\mathrm{Na}_{2} \mathrm{SO}_{3}$, all from Vetec, were used as received. A solution of ammonium metavanadate (Vetec) was prepared at a concentration of $0.060 \mathrm{~mol} \mathrm{~L}^{-1}$ in $0.36 \mathrm{~mol} \mathrm{~L}^{-1} \mathrm{H}_{2} \mathrm{SO}_{4}$ and used for $\mathrm{H}_{2} \mathrm{O}_{2}$ quantification.

All experiments were carried out using the commercial formulation ( $276 \mathrm{~g} \mathrm{~L}^{-1}$ of PQT, $\mathrm{C}_{12} \mathrm{H}_{14} \mathrm{Cl}_{2} \mathrm{~N}_{2}=257 \mathrm{~g} \mathrm{~mol}^{-1}$ ), diluted to obtain $50 \mathrm{mg} \mathrm{L}^{-1} \mathrm{PQT}$ in solution. Although the PQT concentration is higher than that found in aquatic environments, it was chosen to permit an adequate evaluation of the toxicity. An analytical standard of PQT for chromatographic analysis was purchased from Sigma-Aldrich. High performance liquid chromatography (HPLC) analyses were done using HPLC grade methanol (Vetec).

\section{Experimental design}

The central composite design (CCD) was applied to optimize the concentration of the variables $\left(\mathrm{Fe}^{2+}\right.$ and $\mathrm{H}_{2} \mathrm{O}_{2}$ ), able to induce a high percentage of mineralization of commercial formulation by the photo-Fenton process, as well as to evaluate the interactions among these two variables. The percentage of mineralization, measured by total organic carbon (TOC) decay after $60 \mathrm{~min}$ of reaction in relation to the initial TOC value, was chosen as the response factor of the photo-Fenton process. CCD is a star type project that consists of three series of experiments: $(i)$ a $2^{\mathrm{k}}$ factorial design (all possible combinations of codified values between +1.0 and -1.0 ) for $\mathrm{k}=2$ variables consists of four experiments; (ii) axial or star points $(+1.4$ and -1.4 ), and 0 for two variables (four experiments); and (iii) replicates of the central point (0) (five experiments). Thus, for this design, it was necessary to do thirteen experiments, in which the two variables were codified in five levels, varying within the following ranges: $\mathrm{Fe}^{2+}$ (7.2-12.8 $\mathrm{mg} \mathrm{L}^{-1}$ ) and $\mathrm{H}_{2} \mathrm{O}_{2}\left(39.8-232.2 \mathrm{mg} \mathrm{L}^{-1}\right)$. The ranges of the variables were chosen according to previous studies. ${ }^{27-30}$ For CCD, the equations used to quantitatively describe each system and draw the response surface and contour plots were built using STATISTICA 6.0 software. Statistical validation was obtained using the analysis of variance (ANOVA) test at $95 \%$ confidence level.

\section{Photodegradation procedures}

\section{Lab-scale experiments}

The photodegradation experiments were performed in lab-scale using a $400 \mathrm{~W}$ high pressure mercury vapor lamp as irradiation source. The photocatalytic reactor consists of an annular recipient of borosilicate glass with an irradiated surface of $3.89 \times 10^{-2} \mathrm{~m}^{2}$. The lamp was positioned at 
the center of the reactor, as described and schematically presented by Oliveira et al..$^{31}$ The average irradiance of UVA radiation measured for the $1 \mathrm{amp}^{32}$ is $1100 \mathrm{~W} \mathrm{~m}^{-2}$, which presents a photonic flux of $3.3 \times 10^{-6}$ einstein $\mathrm{s}^{-1}$ between 295 and $710 \mathrm{~nm} .{ }^{33}$ The measurements were done using a Solar Light PMA 2100 photometer/radiometer, equipped with an UVA detector (320-400 $\mathrm{nm}$ ) and a radiometric/ photometric setup, ${ }^{33}$ built with components furnished by Ocean Optics, Inc.

The irradiated volume of the reactor was $0.280 \mathrm{~L}$ and a total volume of $4 \mathrm{~L}$ of commercial formulation was recirculated, by pumping at a flow rate of $2.14 \mathrm{~L} \mathrm{~min}^{-1}$ after the addition of iron solution, $\mathrm{pH}$ adjustment between 2.5 and 2.8 (the optimum $\mathrm{pH}$ range for the Fenton reaction) and addition of $\mathrm{H}_{2} \mathrm{O}_{2}$. The lamp was only turned on when the reactor was filled with solution.

For CCD experiments, aliquots of the photolyzed solutions $(20 \mathrm{~mL})$ were collected only after $60 \mathrm{~min}$ of reaction, while for the kinetic experiment, samples $(70 \mathrm{~mL})$ were collected at $20 \mathrm{~min}$ intervals up to $120 \mathrm{~min}$. The initial conditions used in CCD design are described in the section of the experimental design.

The kinetic experiments were carried out using initially $50.0 \mathrm{mg} \mathrm{L}^{-1}$ PQT, $11.8 \mathrm{mg} \mathrm{L}^{-1} \mathrm{Fe}^{2+}$ and $188.1 \mathrm{mg} \mathrm{L}^{-1}$ $\mathrm{H}_{2} \mathrm{O}_{2}$, the last replaced in 60 and $100 \mathrm{~min}$ of reaction due to its consumption. After sampling and before analysis, a calculated volume of $2.0 \mathrm{~mol} \mathrm{~L}^{-1} \mathrm{Na}_{2} \mathrm{SO}_{3}$ solution was added to the samples, according to the stoichiometry between $\mathrm{H}_{2} \mathrm{O}_{2}$ and $\mathrm{Na}_{2} \mathrm{SO}_{3}$, and $\mathrm{H}_{2} \mathrm{O}_{2}$ concentration. This procedure ensures the removal of the remaining $\mathrm{H}_{2} \mathrm{O}_{2}$, interrupting the Fenton reaction. Also, it eliminates the interference caused by traces of $\mathrm{H}_{2} \mathrm{O}_{2}$ in toxicity assays and avoids the sulfite interference on the chemical oxidation demand (COD) measurements. ${ }^{34}$

For the toxicity assays, the $\mathrm{pH}$ value was adjusted in the range between 6 and 8 after adding the $\mathrm{Na}_{2} \mathrm{SO}_{3}$ solution. The solution temperature was controlled using a thermostatic bath (Tecnal TE-184), keeping close to $25 \pm 2{ }^{\circ} \mathrm{C}$. Control experiments were performed using the same experimental setup previously described for the kinetic photo-Fenton experiments.

\footnotetext{
Experiments in a pilot plant: use of solar radiation

Experiments using solar radiation were carried out during Autumn, under clear sky conditions, using a solar pilot plant. The solar irradiance was measured using a radiometer (PMA 2100, Solar Light, Co.) in the UVA region $(320-400 \mathrm{~nm})$, with the sensor attached with the same inclination of the reflective surface of the reactor. ${ }^{35}$ Under this condition, an average solar irradiance of $36.4 \pm 5.4 \mathrm{~W} \mathrm{~m}^{-2}$ was obtained between 9:45 and 11:45 am in May/2012.
}

The solar reactor is a compound parabolic collector (CPC) with an irradiated surface of $1.62 \mathrm{~m}^{2}$ (irradiated volume: $12 \mathrm{~L}$ ) and a reservoir with maximum capacity of $120 \mathrm{~L} .^{35}$ A volume of $50 \mathrm{~L}$ of the PQT solution was circulated under turbulent flow $\left(33.3 \mathrm{~L} \mathrm{~min}^{-1}\right)$ into the CPC absorber tubes in a closed recirculating system. The photoreactor hydraulic circuit consists of a continuously stirred tank and a $0.50 \mathrm{HP}$ centrifugal pump. At the beginning of the experiment, with the collectors covered, the same initial conditions defined for the reagents in kinetic experiments using lab-scale reactor were used. The cover was then removed and samples were collected at intervals of $20 \mathrm{~min}$ up to $120 \mathrm{~min}$. The same treatment previously described, using $\mathrm{Na}_{2} \mathrm{SO}_{3}$ solution, was done to stop the Fenton reaction.

In this experiment, new additions of $\mathrm{H}_{2} \mathrm{O}_{2}$ were done at 60,80 and $100 \mathrm{~min}$ of reaction.

\section{Measurements of the accumulated UVA energy}

It is important to mention that due the differences of the reactors, like as the average irradiance, surface area, total volume of solution, the accumulated UVA energy $\left(Q_{U V A, n}\right.$, $\mathrm{kJ} \mathrm{L}^{-1}$ ) was calculated for each time of sampling in each reactor to allow a good comparison of the results. Equation 1 allows to estimate the amount of accumulated UVA energy $\left(\mathrm{Q}_{\mathrm{UVA}, \mathrm{n}}\right)$ received on any surface per unit of volume, for a solution inside the reactor, in a time interval $\Delta \mathrm{t} .{ }^{36}$

$\mathrm{Q}_{U V A, n}=\mathrm{Q}_{\mathrm{UVA}, \mathrm{n}-1}+\Delta \mathrm{t}_{\mathrm{n}} \overline{\mathrm{UVA}}_{\mathrm{G}, \mathrm{n}}\left(\frac{\mathrm{A}_{\mathrm{r}}}{\mathrm{V}_{\mathrm{t}}}\right)$

where $t_{n}$ is the sampling time, $V_{t}$ is the total reactor volume, $\mathrm{A}_{\mathrm{r}}$ the illuminated collector surface area and $\mathrm{UVA}_{\mathrm{G}, \mathrm{n}}$ the average solar or artificial UVA radiation, measured during the period $\Delta \mathrm{t}_{\mathrm{n}}\left(\mathrm{t}_{\mathrm{n}}-\mathrm{t}_{\mathrm{n}-1}\right)$.

Table 1 presents the accumulated UVA energy for each reactor corresponding to the sampling times of 20,40, $60,80,100$ and $120 \mathrm{~min}$. A significant difference in the accumulated UVA energy was obtained for both reactors. An accumulated UVA energy 10 times higher than that provided by solar radiation to the pilot plant is provided by the mercury lamp to the lab-scale reactor. In the X-axis of Figures 3 and 4, the sampling time was maintained for comparison with control experiments done in the dark, in function of the reaction time.

\section{Analysis}

Before chemical analyses, except for TOC determination, the samples were filtered through membranes with pore 
Table 1. Accumulated UVA energy per unit of volume $\left(\mathrm{Q}_{\mathrm{UVA}}\right)$ for the experiments carried out at lab-scale and in a solar pilot plant

\begin{tabular}{lcc}
\hline \multirow{2}{*}{ time / min } & \multicolumn{2}{c}{$\mathrm{Q}_{\mathrm{UVA}} /\left(\mathrm{kJ} \mathrm{L}^{-1}\right)$} \\
\hline \cline { 2 - 3 } 20 & Lab-scale & Solar pilot plant \\
40 & 214 & 21.7 \\
60 & 428 & 42.8 \\
80 & 642 & 65.9 \\
100 & 856 & 92.1 \\
120 & 1070 & 119.5 \\
\hline
\end{tabular}

diameter of $0.45 \mu \mathrm{m}$. Mineralization, conversion of the organic matter to carbon dioxide and water, of PQT present in a commercial formulation was followed measuring the TOC decay using a TOC analyzer (Shimadzu TOC-VCPH/CPN) equipped with an ASI-V auto sampler. The determination consists of two analyses: first the total carbon (TC) of the sample is determined after catalytic oxidation at high temperature, while the total inorganic carbon (TIC) is determined by equilibrium shift after addition of phosphoric acid to the sample. In both analyses, the $\mathrm{CO}_{2}$ released is determined by infrared spectroscopy.

The TOC concentration includes the carbon content of the target compound, the intermediates generated during the experiment and the excipient of the commercial product. It is calculated by the difference between TC and TIC. Hydrogen peroxide was quantified spectrophotometrically using ammonium metavanadate, monitoring the absorption of the red-orange peroxovanadium cation, at $450 \mathrm{~nm}$ (equation 2). ${ }^{37}$

$\mathrm{VO}_{3}^{-}+4 \mathrm{H}^{+}+\mathrm{H}_{2} \mathrm{O}_{2} \rightarrow \mathrm{VO}_{2}^{3+}+3 \mathrm{H}_{2} \mathrm{O}$

Kinetic experiments were also carried out by HPLC analyses aiming to evaluate the PQT removal, as well as the toxicity and COS. The PQT concentrations were determined by reversed phase HPLC, using a VWR-Hitachi L-2130 chromatograph with UV-Vis detector (Merck-Hitachi L-4250) and a $\mathrm{C}_{18}$ column (Lychrispher, $5 \mu \mathrm{m}, 250 \times 4.6 \mathrm{~mm}$ ). The separation occurred using a mixture of $3 \mathrm{mmol} \mathrm{L}^{-1} \mathrm{HCl}$ and methanol $(25: 75, \mathrm{v} / \mathrm{v})$ in

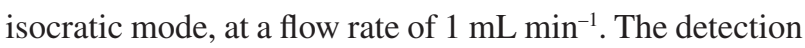
was performed by UV absorption at $257 \mathrm{~nm}$. The injection volume was $20 \mu \mathrm{L}$. Under these conditions, the retention time for PQT was between 2.6 and $2.8 \mathrm{~min}$, with a limit of quantitation of $1.0 \mathrm{mg} \mathrm{L}^{-1}$.

$\mathrm{COD}$, quantity of oxygen required to chemically oxidize organic matter without the intervention of microorganisms, was estimated by absorbance measurement at $420 \mathrm{~nm}$ by means a standard photometric method $(5220 \mathrm{D}){ }^{38}$ This parameter was determined after digestion of the organic matter with dichromate solution in closed reflux vessels at $150{ }^{\circ} \mathrm{C}$ for $2 \mathrm{~h}$.

$\mathrm{COS}$ of the solutions treated by photo-Fenton process was estimated according to equation 3 , where TOC and COD are expressed in $\mathrm{mg} \mathrm{C} \mathrm{L}^{-1}$ and $\mathrm{mg} \mathrm{O}_{2} \mathrm{~L}^{-1}$, respectively. $\mathrm{COS}$ is between +4 for $\mathrm{CO}_{2}$, the most oxidized state of $\mathrm{C}$, and -4 for $\mathrm{CH}_{4}$, the most reduced state of C. ${ }^{34}$

$\mathrm{COS}=4-1.5 x\left(\frac{\mathrm{COD}}{\mathrm{TOC}}\right)$

The toxicity tests were done evaluating the immobilization of Artemia salina, as described by Trovó et al. ${ }^{30}$

\section{Results and Discussion}

Optimization of Fenton's reagents for the mineralization of $\mathrm{PQT}$ in a commercial formulation using experimental design

Before evaluating the degradation kinetics of PQT, CCD was held with the purpose of evaluating the role of each reagent, optimizing their concentration, so as to ensure maximum efficiency for photo-Fenton reaction. Table 2 shows the experimental planning in CCD as well as the response obtained in each experiment in terms of mineralization of PQT present in a commercial formulation.

Equation 4 was obtained using statistical analysis of the experimental data presented in Table 2.

$$
\begin{aligned}
\operatorname{TOC}(\%)= & -218.55+44.01\left[\mathrm{Fe}^{2+}\right]-2.30\left[\mathrm{Fe}^{2+}\right]^{2}+0.20\left[\mathrm{H}_{2} \mathrm{O}_{2}\right]- \\
& 0.002\left[\mathrm{H}_{2} \mathrm{O}_{2}\right]^{2}+0.05\left[\mathrm{Fe}^{2+}\right]\left[\mathrm{H}_{2} \mathrm{O}_{2}\right]
\end{aligned}
$$

The effect of each process independent variable can be directly correlated to its coefficient. ${ }^{27,30}$

From equation 4 , although negative quadratic coefficients have been obtained for $\mathrm{Fe}^{2+}(-2.30)$ and $\mathrm{H}_{2} \mathrm{O}_{2}(-0.002)$, the expressive positive linear coefficients for $\mathrm{Fe}^{2+}(+44.01)$ and $\mathrm{H}_{2} \mathrm{O}_{2}(+0.20)$, and the positive coefficient found for the interaction between $\mathrm{Fe}^{2+}$ and $\mathrm{H}_{2} \mathrm{O}_{2}(+0.05)$, suggest that the mineralization is favored increasing their concentrations. The overall effect can be observed in Figure 2, that presents a diagram that represents the polynomials related to photoFenton reaction, constructed from the results presented in Table 2. An analysis of the surface (Figure 2) suggests that a high percentage of mineralization can be obtained using $11.8 \mathrm{mg} \mathrm{L}^{-1} \mathrm{Fe}^{2+}$ and $188.1 \mathrm{mg} \mathrm{L}^{-1} \mathrm{H}_{2} \mathrm{O}_{2}$.

An experiment was performed in order to check the optimized values, predicted by the mathematical model. The theoretical result, calculated using equation 4 , shows a very good agreement with the experimental results 
Table 2. Central composite design and experimental results for mineralization of PQT in a commercial formulation after $60 \mathrm{~min}\left(642 \mathrm{~kJ} \mathrm{~L}^{-1}\right.$ of UVA radiation) of photo-Fenton process

\begin{tabular}{lcccc}
\hline \multirow{2}{*}{ Experiment } & \multicolumn{2}{c}{ Concentration (codified value) } & Consumption of $\mathrm{H}_{2} \mathrm{O}_{2} / \%$ & Mineralization / \% \\
\cline { 2 - 4 } 1 & $\mathrm{Fe}^{2+} /\left(\mathrm{mg} \mathrm{L}^{-1}\right)$ & $\mathrm{H}_{2} \mathrm{O}_{2} /\left(\mathrm{mg} \mathrm{L}^{-1}\right)$ & 100 & 17.6 \\
2 & $8.0(-1)$ & $68.0(-1)$ & 56.4 & 14.8 \\
3 & $8.0(-1)$ & $204.0(+1)$ & 98.8 & 27.2 \\
4 & $12.0(+1)$ & $68.0(-1)$ & 100 & 54.1 \\
5 & $12.0(+1)$ & $204.0(+1)$ & 78.9 & 22.8 \\
6 & $7.2(-1.4)$ & $136.0(0)$ & 100 & 50.1 \\
7 & $12.8(+1.4)$ & $136.0(0)$ & 98.2 & 16.8 \\
8 & $10.0(0)$ & $39.8(-1.4)$ & 96.7 & 51.5 \\
9 & $10.0(0)$ & $232.2(+1.4)$ & 100 & 51.5 \\
10 & $10.0(0)$ & $136.0(0)$ & 100 & 49.8 \\
11 & $10.0(0)$ & $136.0(0)$ & 100 & 47.3 \\
12 & $10.0(0)$ & $136.0(0)$ & 100 & 55.6 \\
13 & $10.0(0)$ & $136.0(0)$ & 100 & 5.8 \\
\hline Standard deviation of central points (experiments 9-13) & $136.0(0)$ & & \\
\hline
\end{tabular}

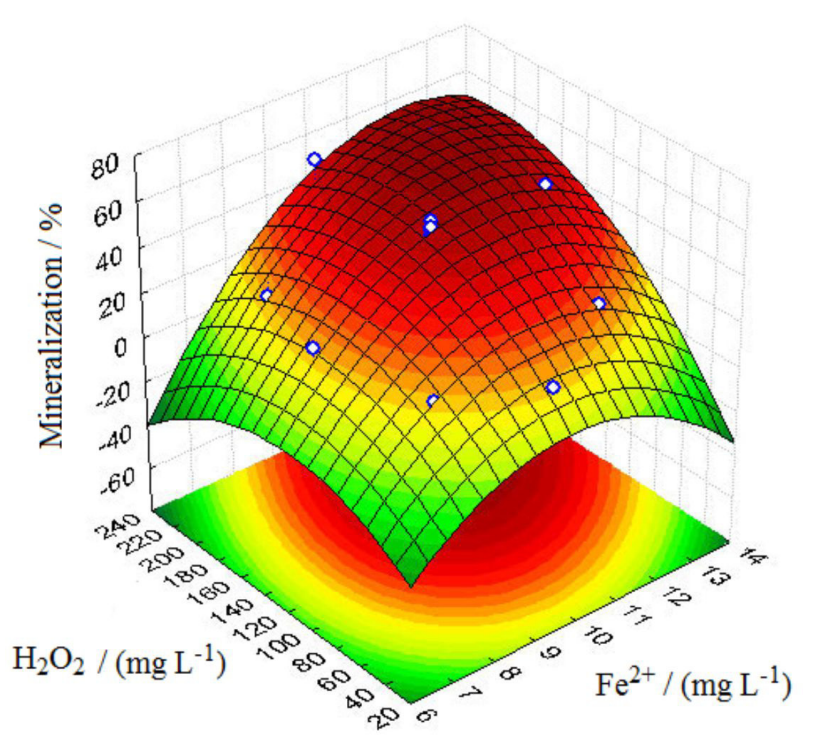

Figure 2. Response surface of quadratic models for the mineralization of PQT in a commercial formulation after $60 \min \left(642 \mathrm{~kJ} \mathrm{~L}^{-1}\right.$ of UVA radiation) of photo-Fenton process.

obtained for the optimal concentration of $\mathrm{Fe}^{2+}$ and $\mathrm{H}_{2} \mathrm{O}_{2}$ (Table 3), assuming a standard deviation of $\pm 3.1 \%$ for mineralization (value obtained from five replicates in the central point of CCD). This demonstrates that the surface response methodology can be useful as a tool to optimize the degradation of organic matter in reactions mediated by photo-Fenton process.

\section{Kinetics of PQT degradation and toxicity assessment}

Using the optimized conditions defined by the analysis of the response surface from the results obtained
Table 3. Optimized values for the studied variables and comparison between experimental and theoretical results

\begin{tabular}{lccc}
\hline Variable & $\begin{array}{c}\text { Concentration / } \\
\left(\mathrm{mg} \mathrm{L}^{-1}\right)\end{array}$ & \multicolumn{2}{c}{ Mineralization / \% } \\
\cline { 3 - 4 } & 11.8 & Theoretical & Experimental \\
\hline $\mathrm{Fe}^{2+}$ & 188.1 & 58.4 & 64.6 \\
$\mathrm{H}_{2} \mathrm{O}_{2}$ & & & \\
\hline
\end{tabular}

at lab-scale, the degradation profile of PQT and its mineralization in a commercial formulation (Figure 3), as well as assessment of the toxicity and COS (Figure 4) during photo-Fenton process at lab-scale and in a solar pilot plant was obtained.

The PQT concentration reached the limit of quantitation $\left(1.0 \mathrm{mg} \mathrm{L}^{-1}\right)$ at lab-scale after $20 \mathrm{~min}\left(214 \mathrm{~kJ} \mathrm{~L}^{-1}\right.$ of UVA radiation) while $40 \mathrm{~min}\left(42.8 \mathrm{~kJ} \mathrm{~L}^{-1}\right.$ of UVA radiation) were necessary when the solar pilot plant was used (Figure 3a). Similar behavior was also observed during the mineralization of PQT by photo-Fenton treatment (Figure $3 b$ ). A rapid decay of mineralization at lab-scale was obtained in relation to the solar pilot plant. This can be attributed to the higher accumulated UVA energy at lab-scale (Table 1). However, after 120 min of photo-Fenton treatment, a similar efficiency was reached for both reactors (89.4 at lab-scale and $84.1 \%$ at solar pilot plant), even assuming a standard deviation of $\pm 3.1 \%$ for mineralization (Table 2). In addition, a lower accumulated UV energy at solar pilot plant (146.9 $\mathrm{kJ} \mathrm{L}^{-1}$ of UVA radiation) was necessary to obtain the same efficiency in relation labscale (1284 kJ L L $\mathrm{k}^{-1}$ UVA radiation). Nogueira et al. ${ }^{39}$ evaluated the influence of the solar light intensity on the TOC removal and observed that the degradation rate 
(a)

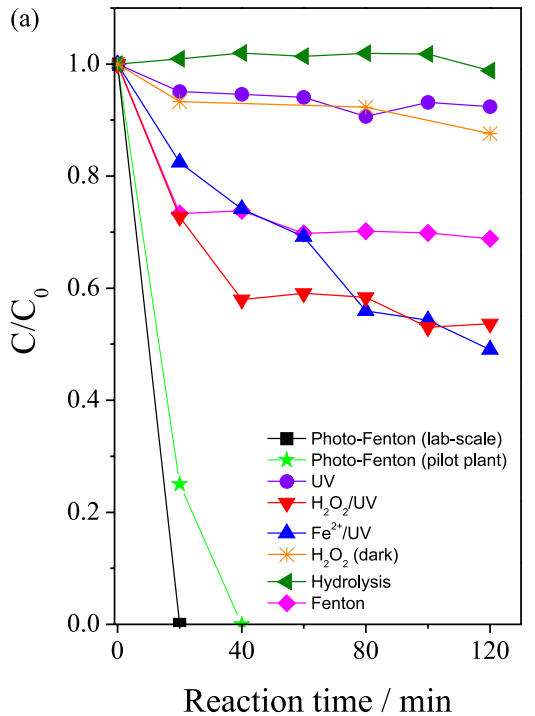

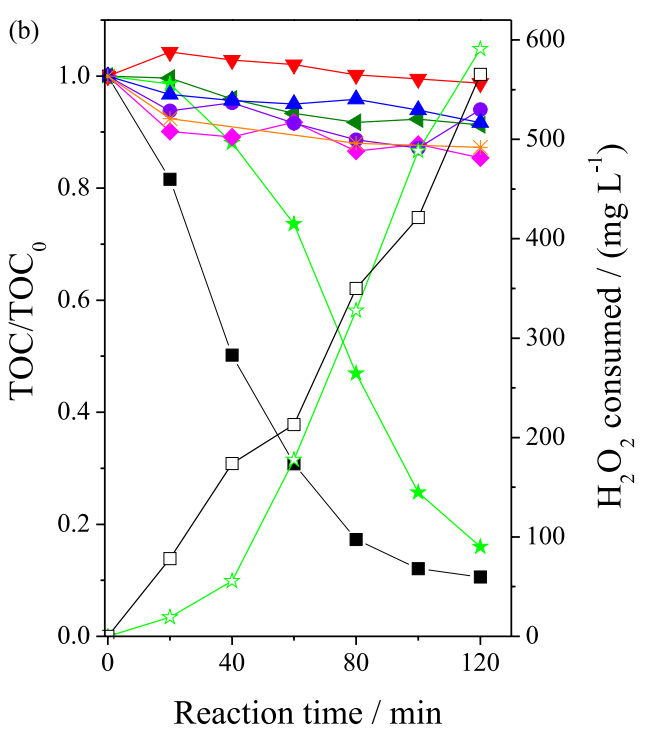

Figure 3. Profiles of (a) PQT and (b) TOC removal (solid symbols) and consumption of $\mathrm{H}_{2} \mathrm{O}_{2}$ (open symbols) during the degradation of PQT present in a commercial formulation by photo-Fenton process at lab-scale and in a solar pilot plant, compared to control experiments (lab-scale). Initial conditions: $[\mathrm{PQT}]=50 \mathrm{mg} \mathrm{L}^{-1}(\mathrm{TOC}=59 \mathrm{mg} \mathrm{C} \mathrm{L}-1),\left[\mathrm{Fe}^{2+}\right]=11.8 \mathrm{mg} \mathrm{L}^{-1},\left[\mathrm{H}_{2} \mathrm{O}_{2}\right]=188.1 \mathrm{mg} \mathrm{L}^{-1}$ and $\mathrm{pH}=2.5-2.8$. New additions of $\mathrm{H}_{2} \mathrm{O}_{2}$ were done at 60 and 100 min lab-scale (642 and $1070 \mathrm{~kJ} \mathrm{~L}^{-1}$ of UVA radiation) and 60, 80 and $100 \mathrm{~min}$ at solar pilot plant $\left(65.9,92.1\right.$ and $119.5 \mathrm{~kJ} \mathrm{~L}^{-1}$ of UVA radiation, respectively) during the photo-Fenton process.

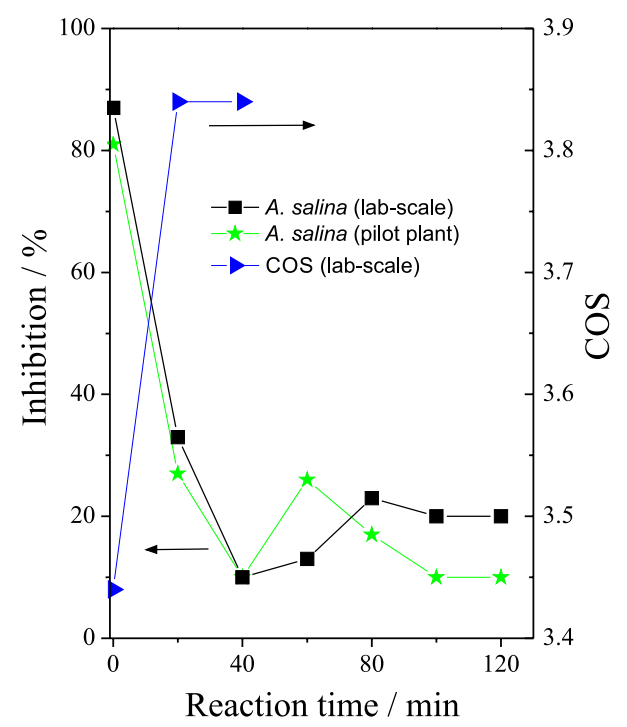

Figure 4. Profiles of evolution of toxicity (at lab-scale and in a solar pilot plant) and COS (at lab-scale) during the degradation of PQT in a commercial formulation by photo-Fenton process. Initial conditions: $[\mathrm{PQT}]=50 \mathrm{mg} \mathrm{L}^{-1}\left(\mathrm{TOC}=59 \mathrm{mg} \mathrm{C} \mathrm{L}^{-1}\right),\left[\mathrm{Fe}^{2+}\right]=11.8 \mathrm{mg} \mathrm{L}^{-1}$ $\left[\mathrm{H}_{2} \mathrm{O}_{2}\right]=188.1 \mathrm{mg} \mathrm{L}^{-1}$ and $\mathrm{pH}=2.5-2.8$. New additions of $\mathrm{H}_{2} \mathrm{O}_{2}$ were done at 60 and $100 \mathrm{~min}$ lab-scale (642 and $1070 \mathrm{~kJ} \mathrm{~L}^{-1}$ of UVA radiation) and 60,80 and $100 \mathrm{~min}$ at solar pilot plant $\left(65.9,92.1\right.$ and $119.5 \mathrm{~kJ} \mathrm{~L}^{-1}$ of UVA radiation, respectively).

increases linearly with the light intensity for values up to $15 \mathrm{~W} \mathrm{~m}^{-2}$, but above this value, the degradation is best described by a square root relationship, which justifies the results obtained in this work. Although a $400 \mathrm{~W}$ high pressure mercury vapor lamp (average irradiance of $1100 \mathrm{~W} \mathrm{~m}^{-2}$ ) was used as irradiation source at lab-scale, the same efficiency was obtained in a solar pilot plant with an average solar irradiance of $36.4 \pm 5.4 \mathrm{~W} \mathrm{~m}^{-2}$. The consumption of hydrogen peroxide agrees with the results of mineralization (Figure 3b). After 120 min (146.9 and $1284 \mathrm{~kJ} \mathrm{~L}^{-1}$ of UVA radiation, respectively under solar irradiation and in lab-scale) of photo-Fenton treatment, 565 and $591 \mathrm{mg} \mathrm{L}^{-1}$ of $\mathrm{H}_{2} \mathrm{O}_{2}$ were consumed at lab-scale and solar pilot plant experiments, respectively (Figure $3 b$ ). The $\mathrm{H}_{2} \mathrm{O}_{2}$ consumption profile shows a linear correlation with the reaction time $\left(\alpha=4.7\right.$ and $4.9 \mathrm{mg} \mathrm{H}_{2} \mathrm{O}_{2} \mathrm{~min}^{-1}$ at lab-scale and in a solar pilot plant, respectively). For this same sequence, under the operating conditions, 10.8 and $12.4 \mathrm{mg} \mathrm{H}_{2} \mathrm{O}_{2}$ were consumed for each $\mathrm{mg}$ of TOC mineralized (Figure 3b).

Control experiments at lab-scale were also performed for an initial PQT concentration equal to $50 \mathrm{mg} \mathrm{L}^{-1}$ in the: (i) absence of $\mathrm{Fe}^{2+}$ and $\mathrm{H}_{2} \mathrm{O}_{2}$ (direct photolysis at $\mathrm{pH}$ 6.3, natural $\mathrm{pH}$ of the solution); (ii) dark, without $\mathrm{Fe}^{2+}$ and in the presence of $\mathrm{H}_{2} \mathrm{O}_{2}\left(188.1 \mathrm{mg} \mathrm{L}^{-1}\right.$ ); (iii) presence of UV irradiation and $188.1 \mathrm{mg} \mathrm{L}^{-1} \mathrm{H}_{2} \mathrm{O}_{2}$ at $\mathrm{pH}$ 6.3, without $\mathrm{Fe}^{2+}$; (iv) hydrolysis at $\mathrm{pH} 2.5$; (v) presence of $\mathrm{UV}$ irradiation and $11.8 \mathrm{mg} \mathrm{L}^{-1} \mathrm{Fe}^{2+}$ at $\mathrm{pH} 2.5$, without $\mathrm{H}_{2} \mathrm{O}_{2}$; and (vi) presence of $11.8 \mathrm{mg} \mathrm{L}^{-1} \mathrm{Fe}^{2+}$ and $188.1 \mathrm{mg} \mathrm{L}^{-1} \mathrm{H}_{2} \mathrm{O}_{2}$ in the dark (Figure 3). A lower removal of $\mathrm{PQT}$ and mineralization was obtained for all control experiments, when compared to the photo-Fenton process, evidencing its high efficiency and assuring that the results found are consistent and not due to hydrolysis, thermal Fenton process, and/or direct or due to hydrogen peroxide photolysis (Figure 3).

COSs for the samples in reactions mediated at labscale, and toxicity at lab-scale and using a solar pilot plant, 
were also analyzed during PQT degradation aiming to evaluate the toxicity behavior and COS variation during application of the photo-Fenton process under optimum conditions. The assessment of the toxicity during the degradation of pesticides is critical when a process is studied as an alternative to wastewater treatment, or when this same process is regarded as the first stage in a treatment process coupled to a subsequent biological process. $^{40}$

The solution containing $50 \mathrm{mg} \mathrm{L}^{-1}$ of PQT showed a high value of COS $(+3.44)$, suggesting that the compound has a high COS (Figure 4). However, this value does not show correspondence with the theoretical value. The experimental COD value obtained for the experimental TOC initial concentration of commercial formulation is equivalent to only $14.0 \%$ of the theoretical value $\left(157 \mathrm{mg} \mathrm{O}_{2} \mathrm{~L}^{-1}\right)$. This low experimental COD value obtained in relation the experimental initial TOC (59 $\left.\mathrm{mg} \mathrm{C} \mathrm{L}^{-1}\right)$ contributes to generate a high experimental $\operatorname{COS}$ (equation 3 ), higher than the theoretical value $(\mathrm{COS}=0.0008)$. This lower value measured for COD is probably due to the presence of two pyridine rings on PQT structure, a refractory species to APHA method for determination of COD. ${ }^{34}$

Applying the photo-Fenton process at lab-scale, the PQT concentration reached the limit of quantitation (1.0 mg L ${ }^{-1}$ ) with $18 \%$ of TOC removal (Figure 3 ) and an increase in COS from +3.44 to +3.84 (Figure 4), in only $20 \mathrm{~min}$ of reaction (214 $\mathrm{kJ} \mathrm{L}^{-1}$ of UVA radiation), after consumption of $78 \mathrm{mg} \mathrm{L}^{-1} \mathrm{H}_{2} \mathrm{O}_{2}$. In this same period, the acute toxicity, calculated by the inhibition of mobility of A. salina, decreased from 87 to $33 \%$ (Figure 4), which is related with the PQT concentration reduction (Figure $3 \mathrm{a}$ ). With the increase of the reaction time up to $40 \mathrm{~min}$ ( $428 \mathrm{~kJ} \mathrm{~L}^{-1}$ of UVA radiation), a consumption of $174 \mathrm{mg} \mathrm{L}^{-1} \mathrm{H}_{2} \mathrm{O}_{2}$, a TOC removal of $50 \%$ (Figure $3 \mathrm{~b}$ ), the same COS value of +3.84 and a decrease in the toxicity from 33 to $10 \%$ (Figure 4) were reached. Although the COS values obtained do not show correspondence with the theoretical data, the application of photo-Fenton process contributed to the formation of intermediates more oxidized and a lower toxicity than the verified for the initial sample containing only PQT. After $60 \mathrm{~min}$ (642 $\mathrm{kJ} \mathrm{L}^{-1}$ of UVA radiation) of reaction and consumption of $213 \mathrm{mg} \mathrm{L}^{-1} \mathrm{H}_{2} \mathrm{O}_{2}, 69 \%$ of TOC removal (Figure $3 \mathrm{~b}$ ) and a toxicity of $13 \%$ (Figure 4 ) were obtained. It was not possible to calculate the COS value after $60 \mathrm{~min}\left(642 \mathrm{~kJ} \mathrm{~L}^{-1}\right.$ of UVA radiation) of reaction, once that the COD values obtained were null. For an irradiation time up to $120 \mathrm{~min}\left(1284 \mathrm{~kJ} \mathrm{~L}^{-1}\right.$ of UVA radiation) and consumption of $565 \mathrm{mg} \mathrm{L}^{-1} \mathrm{H}_{2} \mathrm{O}_{2}$, $89 \%$ of TOC removal (Figure $3 \mathrm{~b}$ ) and a toxicity of $20 \%$ were reached (Figure 4). Similar behavior was obtained to toxicity when the experiment was carried out in a solar pilot plant, however with a lower accumulated UVA energy (Figure 4 and Table 1). The residual toxicity, between $10-20 \%$ in both reactors (Figure 4) is probably due the formation of carboxylic acids, as already observed for Daphnia magna and Vibrio fischeri during degradation of sulfamethoxazole and amoxicillin. ${ }^{41,42}$

On the other hand, Santos et al. ${ }^{24}$ observed a decrease in the biodegradability and no toxicity reduction during PQT degradation by the Fenton's process after $25 \mathrm{~h}$ using the initial conditions: $100 \mathrm{mg} \mathrm{L}^{-1} \mathrm{PQT}, 28 \mathrm{mg} \mathrm{L}^{-1} \mathrm{Fe}^{2+}$ and $221 \mathrm{mg} \mathrm{L}^{-1} \mathrm{H}_{2} \mathrm{O}_{2}$. Probably this difference, compared to our best results, may be due to different initial concentration of PQT and reagents, the removal of TOC reached and/or the concentration of intermediates generated in solution.

In general, it can be observed that after short periods of photo-Fenton process (between 20 and $40 \mathrm{~min}$ ), the toxicity tends to decrease with the PQT concentration reduction and intermediates more oxidized were obtained (Figure 4). So, after these times, probably a biological process could be coupled with the photo-Fenton one, reducing the operational costs of the oxidative treatment. Similar behavior has been observed for other compounds/ wastewaters, during the application of Fenton and photo-Fenton processes. ${ }^{43-46}$

\section{Conclusions}

Based on the experimental results obtained, it is possible to conclude that experimental design and response surface methodology are powerful tools to optimize, in a short set of experiments, the concentration of Fenton reagents, obtaining a high percentage of mineralization of PQT in a commercial formulation. Under optimized conditions, the same efficiency was obtained for both reactors. These results demonstrates that the photo-Fenton process can be applied as an alternative to the wastewater treatment containing this herbicide in large scale and using solar radiation, once that the toxicity decreased significantly with the paraquat concentration reduction and intermediates more oxidized were obtained. In addition, the use of solar radiation is completely advantageous, mainly in tropical countries like Brazil since the energetic costs of the process are reduced to zero.

\section{Acknowledgments}

The authors thank CNPq (Project No. 2011-EXA022) for the scholarship to O. Gomes Junior, and FAPEMIG (CEX-APQ-00915-11, CEX-APQ-01798-11 and 
CEX-APQ-02425-10), CAPES, CNPq (300.587/2008-2 and 304.576/2011-5) for the financial support of this work. A. E. H. Machado is particularly indebted to $\mathrm{CNPq}$ and CAPES for his research grants. The authors also thank to Dr. R. Ruggiero for providing access and use of the HPLC/UV equipment.

\section{References}

1. http://portal.anvisa.gov.br/wps/content/anvisa+portal/anvisa/ sala+de+imprensa/menu+-+noticias+anos/2012+noticias/sem inario+volta+a+discutir+mercado+de+agrotoxicos+em+2012 acessed in November 2012.

2. http://portal.anvisa.gov.br/wps/wcm/connect/7bfd7800474594 009b90df3fbc4c6735/P01++Paraquate.pdf?MOD=AJPERES accessed in November 2012

3. Cheah, U-B.; Kirkwood, R. C.; Lum, K.-Y.; J. Agric. Food Chem. 1998, 46, 1217.

4. Wang, Y.; Yen, J.; Hsien, Y.; Chen, Y.; Water, Air, Soil Pollut. 1994, $72,1$.

5. Tomlim, C. D. S.; The Pesticide Manual, $12^{\text {th }}$ ed.; British Crop Protection Council: UK, 2000.

6. Vidal, J. L. M.; Vega, A. B.; López, F. J. S.; Frenich, A. G.; J. Chromatogr., A 2004, 1050, 179.

7. Fernández, M.; Ibáñez, M.; Picó, Y.; Mañes, J.; Arch. Environ. Contam. Toxicol. 1998, 35, 377.

8. Alberdi, J. L.; Saenz, M. E.; DiMarzio, W. D.; Tortorelli, M. C.; Bull. Environ. Contam. Toxicol. 1996, 57, 229.

9. Ruiz, M. J.; López-Jaramillo, L.; Redondo, M. J.; Font, G.; Bull. Environ. Contam. Toxicol. 1997, 59, 619.

10. Qian, H. F.; Chen, W.; Sun, L. W.; Jin, Y. X.; Liu, W. P.; Fu, Z. W.; Ecotoxicology 2009, 18, 537.

11. Mohammad, M.; Itoh, K.; Suyama, K.; Arch. Environ. Contam. Toxicol. 2010, 58, 605.

12. Jamers, A.; De Coen, W.; Environ. Toxicol. Chem. 2010, 29, 893.

13. Malato, S.; Fernández-Ibáñez, P.; Maldonado, M. I.; Blanco, J.; Gernjak, W.; Catal. Today 2009, 147, 1.

14. Zapata A.; Oller, I.; Sirtori, C.; Rodríguez, A.; Sánchez-Pérez, J. A.; López, A.; Mezcua, M.; Malato, S.; Chem. Eng. J. 2010, 160,447

15. Pintor, A. M. A.; Vilar, V. J. P.; Boaventura, R. A. R.; Sol. Energy 2011, 85, 579

16. Safarzadeh-Amiri, A.; Bolton, J. R.; Carter, S. R.; J. Adv. Oxid. Technol. 1996, 1, 8 .

17. Tennakone, K.; Kottegoda, I. R. M.; J. Photochem. Photobiol., A 1996, 93, 79.

18. Moctezuma, E.; Leyva E.; Monreal, E.; Villegas, N.; Infante, D.; Chemosphere 1999, 39, 511.

19. Lee, J. C.; Kim, M. S.; Kim, C. K.; Chung, C. H.; Cho, S. M.; Han, G. Y.; Yoon, K. J.; Kim, B. W.; Korean J. Chem. Eng. 2003, 20,862 .
20. Lee, J-C.; Kim, M-S.; Kim, B-W.; Water Res. 2002, 36, 1776.

21. Florencio, M. H.; Pires, E.; Castro, A. L.; Nunes, M. R.; Borges, C.; Costa, F. M.; Chemosphere 2004, 55, 345.

22. Ruth, J. M.; Kearney, P. C.; Zeng, Q.; Chemosphere 1985, 14, 1181.

23. Kearney, P. C.; Ruth, J. M.; Zeng, Q.; Mazzocchi, P.; J. Agric. Food Chem. 1985, 33, 953.

24. Santos, M. S. F.; Alves, A.; Madeira, L. M.; Chem. Eng. J. 2011, $175,279$.

25. Dhaouadi, A.; Adhoum, N.; J. Electroanal. Chem. 2009, 637, 33.

26. Dhaouadi, A.; Adhoum, N.; Appl. Catal., B 2010, 97, 227.

27. Trovó, A. G.; Paterlini, W. C.; Nogueira, R. F. P.; J. Hazard. Mater. 2006, 137, 1577.

28. Trovó, A. G.; Nogueira, R. F. P.; Aguera, A.; Fernandez-Alba, A. R.; Sirtori, C.; Malato, S.; Water Res. 2009, 43, 3922.

29. Trovó,A. G.; Nogueira, R. F.P.; J. Braz. Chem. Soc. 2011, 22, 1033.

30. Trovó, A. G.; Silva, T. F. S.; Gomes Jr., O.; Machado, A. E. H.; Borges Neto, W.; Muller Jr., P. S.; Daniel, D.; Chemosphere, 2013, 90, 170.

31. Oliveira, D. F. M.; Batista, P. S.; Muller Jr., P. S.; Velani, V.; França, M. D.; de Souza, D. R.; Machado, A. E. H.; Dyes Pigm. 2012, 92, 563.

32. Machado, A. E. H.; de Miranda, J. A.; de Freitas, R. F.; Mendonça-Duarte, E. T. F.; Ferreira, L. F.; Albuquerque, Y. D. T.; Ruggiero, R.; Sattler, C.; de Oliveira, L.; J. Photochem. Photobiol., A 2003, 155, 231.

33. Machado, A. E. H.; França, M. D.; Velani, V.; Magnino, G. A.; Velani, H. M. M.; Freitas, F. S.; Müller Jr.; P. S.; Sattler, C.; Schmücker, M.; Int. J. Photoenergy 2008, DOI $10.1155 / 2008 / 482373$

34. Vogel, F.; Harf, J.; Hug, A.; Von Rohr, P. R.; Water Res. 2000 , $34,2689$.

35. Duarte, E. T. F. M.; Xavier, T. P.; de Souza, D. R.; de Miranda, J. A.; Machado, A. E. H.; Jung, C.; de Oliveira, L.; Sattler, C; Quim. Nova 2005, 28, 921.

36. Malato, S.; Blanco, J.; Vidal, A.; Richter, C.; Appl. Catal., B. 2002, 37, 1 .

37. Nogueira, R. F. P.; Oliveira, M. C.; Paterlini, W. C.; Talanta 2005, 66, 86 .

38. American Public Health Association (APHA); Standard Methods for the Examination of Water and Wastewater, $16^{\text {th }}$ ed.; APHA: Washington: USA, 1985.

39. Nogueira, R. F. P.; Trovó, A. G.; Modé, D. F.; Chemosphere 2002, 48, 385.

40. Zapata, A.; Velegraki, T.; Sánchez-Pérez, J. A.; Mantzavinos, D.; Maldonado, M. I.; Malato, S.; Appl. Catal., B 2009, 88,448 .

41. Trovó, A. G.; Nogueira, R. F. P.; Aguera, A.; Fernandez-Alba, A. R.; Sirtori, C.; Malato, S.; Water Res. 2009, 43, 3922.

42. Trovó, A. G.; Nogueira, R. F. P.; Aguera, A.; Fernandez-Alba, A. R.; Malato, S.; Water Res. 2011, 45, 1394. 
43. Cassano, D.; Zapata, A.; Brunetti, G.; Del Moro, G.; Di laconi, C.; Oller, I.; Malato, S.; Mascolo, G.; Chem. Eng. J. 2011, 172, 250.

44. Wang, C. W.; Fu, H. X.; Lu, Y.; Zhao, X. F.; Environ. Eng. Sci. 2012, 29, 248.
45. Keskin, T.; Tutuk, F.; Azbar, N.; Chem. Biochem. Eng. Q. 2012, 26, 23.

46. Elmolla, E. S.; Chaudhuri, M.; Desalination 2012, 285, 14.

Submitted: September 23, 2012

Published online: February 7, 2013 